\title{
A Compromised Peace? The Effect of Power-Sharing Arrangements on Post-War Violence*
}

\author{
Martin Ottmann ${ }^{\dagger}$
}

May 7, 2018

\begin{abstract}
How does power-sharing between government and rebels affect the use of violence by political actors outside of peace agreements? To address this puzzle, I propose a political economy model of power-sharing and post-war violence. Power-sharing regulates elites' access to state resources and thus determines whether government and rebels can successfully suppress post-war rebellions. Personalized power-sharing gives elites privileged access to state resources, facilitates effective counter-insurgency strategies, and thus decreases post-war violence. In contrast, structural power-sharing limits elites' access to resources and their ability to prevent armed challenges resulting in higher levels of postwar violence. I test these propositions with a quantitative analysis of peace agreements in Africa and Asia signed between 1990 and 2006. The statistical findings lend support to my theoretical reasoning.
\end{abstract}

Word count: ca. 10,770

*I thank Felix Bethke, Felix Haass, Mike Hanmer, Paul Jackson, Erin Jenne, Charlene Morris, Mansoob Murshed, Stefan Wolff, and participants at the ISA convention 2016 and Jan Tinbergen conference 2017 for helpful comments and advice. I also acknowledge financial support from the German Research Foundation (OT 494/1-1).

'International Development Department, School of Government and Society, University of Birmingham, Birmingham B15 2TT, United Kingdom (e-mail: m.ottmann@bham.ac.uk; website: https://martinottmann.com/). 


\section{Introduction}

On 9 January 2005, one of Africa's longest running civil wars was finally concluded when the Sudanese government and the Sudan People Liberation Army (SPLA) signed the Comprehensive Peace Agreement (CPA). Its central element was an elaborate power-sharing deal involving a Government of National Unity and extensive territorial autonomy for Southern Sudan. It was another instance of what scholars and practitioners alike often regard as an effective way to resolve civil wars: the extensive sharing of power between former combatants on as many dimensions of power as possible (Hartzell and Hoddie 2007). Unfortunately, peace in Sudan was short-lived. Already in 2005, the regime in Khartoum was embroiled in a separate armed conflict in Darfur killing and displacing thousands of civilians. In South Kordofan and Blue Nile states, continued fighting between Sudanese government forces and former SPLA allies also reached new heights very quickly. Moreover, simmering tensions between the Government of South Sudan and regional militias soon escalated into armed violence resulting in a bloody civil war just a few years after South Sudan gained its long-desired independence.

Sudan is not the only post-war country plagued by increasing levels of battle violence between signatories to a peace agreement and armed groups outside the settlement. Such post-war violence can also be observed in the Democratic Republic of Congo, the Philippines or Tajikistan. This highlights an intriguing puzzle. Power-sharing often prevents renewed large-scale violence between the government and rebel signatories to a peace agreement (Hartzell and Hoddie 2007; Mattes and Savun 2009; Walter 2002). But these arrangements frequently do not pacify a post-war country in its entirety. Excluded armed groups continue their fighting while newly emerging armed groups soon join the fray (Boyle 2014; Nilsson and Söderberg Kovacs 2011). To better understand the determinants of post-war violence, scholars have turned to the internal politics of rebel movements and the incentives former combatants might have for renewed violence after war (Cunningham, Bakke, and Seymour 2012; Daly 2014; Themnér 2011; Walter 2004). However, these approaches do not explicate if power-sharing impacts these actors and the wider post-war order. I therefore ask in this article: How does power-sharing between government and rebels affect the incentives and constraints of excluded political actors to use post-war violence?

To provide an answer to this question, I propose a political economy model of powersharing and post-war violence. A peace agreement between government and rebels redistributes political power among its signatories (Hartzell and Hoddie 2007). Its security guarantees act as a commitment device safeguarding that neither government nor rebels defect and return to violence. Equally important, it also regulates which political actors gain access to state resources and which are excluded from them (North, Wallis, and Weingast 2009; North et al. 2013). Agreement signatories use this privileged access to resources to generate rents which they invest in 'stick-and-carrot' counter-insurgency strategies (Grossman 1995; Lichbach 1995). Ideally, these strategies increase individuals' cost of soldiering for armed groups outside the settlement and offer incentives for peaceful behavior. When these two conditions are met, they 
can successfully suppress post-war rebellions and maintain their supreme position in the postwar country. But power-sharing can differ considerably across cases and with these differences come variation in the extent to which agreement signatories can access resources and invest them in counter-insurgency. Executive power-sharing in the national government, for example, is highly personalized and gives elites direct access to resources in order to maintain their armed forces and reward their constituencies. This substantially reduces the political space for post-war rebellions. In contrast, structural power-sharing-for instance, territorial autonomy arrangements-only give elites very limited access to resources for their counter-insurgency efforts. Excluded armed groups can then successfully mobilize and post-war violence is likely to increase.

I test these predictions with a statistical analysis of the effect of power-sharing on postwar violence in African and Asian countries emerging from civil war between 1990 and 2006. I capture the practices of power-sharing using the temporally disaggregated data of the Power-Sharing Event Dataset (PSED) (Ottmann and Vüllers 2015). Post-war violence is measured using monthly fatality data from the Uppsala Conflict Data Program (UCDP) (Sundberg and Melander 2013). The empirical analysis provides empirical support for my argument. Personalized power-sharing which grants government and rebel elites exclusive access to state resources is associated with lower levels of post-war violence. In contrast, structural power-sharing which restricts elites' access to state resources is accompanied by increased levels of post-war violence. These findings are consistent across various model specifications and robust to alternative estimation approaches.

This article makes a number of notable contributions. First, I complement existing theories of power-sharing and post-war peace with a political economy model (Haass and Ottmann 2017). So far, scholars have largely understood power-sharing as a 'security commitment device' which mitigates the security dilemma between former conflict actors by providing guaranteed participation in the political decision-making process (e.g. Cederman et al. 2015; Gates et al. 2016; Hartzell and Hoddie 2007; Walter 2002). My approach conceptualizes power-sharing as also regulating elite access to state resources which, in turn, affects counterinsurgency strategies and the likelihood of post-war violence (Grossman 1995; North, Wallis, and Weingast 2009; North et al. 2013). This perspective highlights a theoretical pathway linking elite pacts to citizens on the ground and political processes in the post-war order in general. It thus links the burgeoning micro-level literature on resource redistribution and rebellions to existing macro-level theories of power-sharing and civil war recurrence.

Second, this study is among the first to comprehensively analyze conceptually and temporally disaggregated data on power-sharing and political violence. Instead of examining the mere promises of power-sharing made in a peace agreement (Binningsbø 2013), I analyze their actual practices on a monthly basis throughout the post-war period using disaggregated event data. This analytical distinction is of utmost importance as promises of power-sharing can differ considerably from their eventual practices (Joshi and Darby 2013; Ottmann and Vüllers 2015). The use of monthly fatality data on battle violence between actors within and outside of 
a settlement, on the other hand, allows me to move beyond the common operationalization of post-war peace as the absence of large-scale civil war between agreement signatories (Mattes and Savun 2009; Hartzell and Hoddie 2007; Walter 2002). This significantly extends our empirical understanding of the relationship between power-sharing and peace.

Finally, this study contributes to the ongoing discussion among policy-makers on whether power-sharing is a 'best practice' for conflict management and resolution. My empirical findings contribute to recent debates over the advantages and shortcomings of particular types of powersharing (Cederman et al. 2015; Gates et al. 2016; Graham, Miller, and Strøm 2017; Hartzell and Hoddie 2015). So far, these discussions have not considered the likelihood that even one particular type of power-sharing on its own can have widely diverging effects on different political actors across a post-war country. My political economy model of power-sharing and post-war violence addresses this gap and provides a framwork for analysis. As power-sharing restructures elite access to state resources, it shapes and reforms patronage networks and patterns of resource redistribution and thus the incentives and constraints of individual citizens living in the new post-war order. When attempting to foster peace through power-sharing, we have to be aware of these mechanisms and consider how power-sharing eventually affects individuals on the ground and their decisions to either (re-)join armed opposition groups or engage in peaceful behavior.

\section{Does Power-Sharing Promote Peace?}

Negotiated settlements address one of the root causes of civil wars: the distribution of power between government and rebels. They reaffirm the incumbent government's control over the state apparatus while granting rebels some access to state power. These arrangements often manifest themselves in power-sharing institutions which "define how decisions will be made by collectivities within the postwar polity as well as to allocate decision-making rights among competing groups" (Hartzell and Hoddie 2007, 13).

Some scholars argue that power-sharing is an effective tool to resolve armed conflict (e.g., Hartzell and Hoddie 2007; Walter 2002). It does not only address the distribution of political power as one of the root causes of civil war, it is also an institutional safeguard and commitment device. Both sides fear that their opponent might defect from the negotiated settlement at any time. The joint control of state institutions addresses these security concerns of government and rebels and alleviates their fear of survival. The definition and allocation of decision-making rights also establishes a set of institutional checks and balances on each side's political and military power.

However, past research has not yet presented clear empirical evidence in support for this assumed relationship between power-sharing and post-war peace (for an overview, see: Binningsb $\varnothing 2013)$. This is due to a conflation of actor-level theories with country-level concepts of war and peace. Scholars have disregarded that credible commitments only bind the signatories 
Figure 1. Temporal Trends in Violence in the First Five Years After Peace Agreements, 19902006
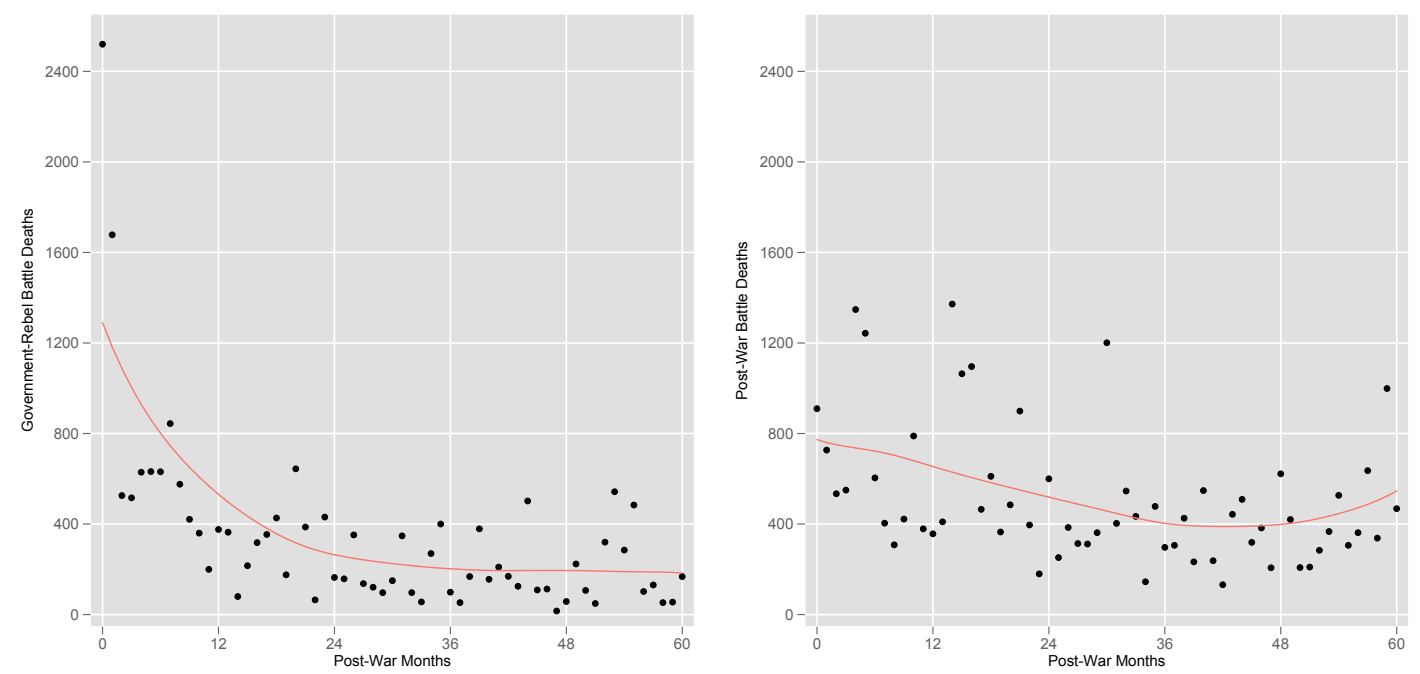

Note: The scatter plots show the monthly averages of battle deaths due to signatory violence (left panel) and post-war violence (right panel). LOESS smoother lines highlight the overall temporal trend.

to the peace agreements and do not reach beyond them. Once we move beyond these actors, we find that some negotiated settlements deliberately exclude some rebel groups whichunsurprisingly - continue or even intensify their armed struggle (Cunningham 2011). Peace agreement also frequently facilitate the fragmentation of government and rebel signatories into smaller factions which are then outside the settlement and resort to violence to get back in (Cunningham, Bakke, and Seymour 2012). Finally, once power-shared is in the capital many former government and rebel commanders might neglect their former combatants causing disaffection and, ultimately, increased levels of post-war violence (Daly 2014; Themnér 2011).

Figure 1 illustrates this situation for African and Asian post-war countries. The left panel plots the temporal trend in monthly averages of battle violence between government and rebel signatories in active peace agreements. One can see a distinct downward trend in the number of battle deaths due to violence between government and rebel signatories. The trend decreases from over 1,200 fatalities in the first post-war month to a monthly number of roughly 200 fatalities five years after a peace agreement. In contrast, monthly data on post-war violence-that is, battle violence between agreement signatories and other armed political groups-show no similar reduction. The trendline plotted in the right panel barely halves from an average of 800 fatalities in the immediate aftermath of a peace agreement to about 500 fatalities after five years. Moreover, there appears to be substantial variation in post-war violence across post-war countries.

To explore these patterns of post-war violence, we have to explicitly address the conceptual mismatch in our theoretical understanding of power-sharing. In particular, we have to model 
how power-sharing shapes the incentives and constrains of all political actors in a post-war order. To this end, I propose a political economy model of power-sharing and post-war violence.

\section{The Political Economy of Power-Sharing and Post-War Violence}

The key actors in any post-war order are violence specialists and a population of producers (North, Wallis, and Weingast 2009; North et al. 2013). Violence specialists are individuals with the capacity to organize large-scale violence. They head organizations composed of mid-level commanders, fighters, and their political and military support networks. In a civil war context, these violence specialists are the state government and any armed opposition groups as, for example, rebel groups or militias. The remainder of the population in a post-war state is made up of civilian producers. These are individuals which have no capacity for large-scale violence themselves. They engage either in production or soldiering for the violence specialists.

\section{Modelling Post-War Rebellions}

Violence specialists and producers interact with each other in three stages (Grossman 1995). In the first stage, a subset of the violence specialists-the elite coalition-comes together under the umbrella of the peace agreement. In the second stage, warlords-violence specialists excluded from the peace agreement-attempt to organize an armed challenge to this elite coalition. It is the main interest of all violence specialists to maximise the expected wealth for themselves and their clientele. In the final stage, producers decide whether and to what extent they engage in production and soldiering for the elite coalition and the warlords. The choice between these two options is guided by the producers' main interest to maximixe their expected income.

When agreeing to a negotiated settlement, violence specialists acting as the state government share and divide their power with some of the challenging violence specialists (Nilsson 2008). The ensuing peace agreement between government and rebels serves two purposes (North, Wallis, and Weingast 2009; North et al. 2013). First, it divides land, labor, capital, and trade among the elites in the coalition and excludes other violence specialists from accessing these resources and productive activities. In doing so, the peace agreement enables members of the elite coalition to follow their individual interests without interference. As long as the benefits derived from the elite coalition exceed the benefits which government and rebel signatories could possibly acquire through a return to a civil war, they will credibly believe that the other side will not resort to arms again. ${ }^{1}$

The second purpose of a peace agreement is to restrict violence between government and rebels and commit each side to defend their agreement if excluded violence specialists should

\footnotetext{
${ }^{1}$ This understanding of peace agreements adds economic commitments to existing explanations focusing on security commitments (e.g. Hartzell and Hoddie 2007; Mattes and Savun 2009; Walter 2002).
} 
challenge them (North, Wallis, and Weingast 2009; North et al. 2013). Only then can both sides continuously enforce each other's privileged access to state resources. The peace agreement endows the elite coalition with the means to accomplish this. They use their privileged access to resources to generate rents which they can spend on a 'stick-and-carrot' counter-insurgency strategy (Grossman 1995). First, elites in the coalition use rents to maintain their armed organizations. ${ }^{2}$ They deploy these armed forces to deter potential insurgents from organizing or suppress actual armed challenges to their rule (Lichbach 1995). Second, elites redistribute their rents across their support networks to strengthen the patron-client relationships between themselves and the producers (Cheng and Zaum 2013; Haass and Ottmann 2017). This incentivizes citizens to engage in production and increases the costs of warlords outside of the coalition to mobilize producers in clientelistic networks for an insurrection.

In the second stage, violence specialists excluded from the peace agreement-warlords-try to insert themselves into the elite coalition (Roessler 2016). These warlords are not given any access to the resources of the post-war state. But they are also not bound by the terms of the negotiated settlement and the security commitment created through its power-sharing institutions. Warlords therefore resort to violence to break up the dominant elite coalition and either insert themselves into the arrangement as additional actors or replace the ruling elites altogether. To have any chance of success, warlords need to arm and build up their own organizations and support networks to a level that poses a credible threat to the elite coalition (Grossman 1995). They need a sufficient number of fighters willing to fight for them, political and material support to arm and equip them, and support from producers (Kalyvas 2006; Weinstein 2007). Central to this endeavor is the compensation they offer to their fighters and supporters if they should defeat the elite coalition.

The final stage of interactions explaining post-war violence focuses on the producers (Grossman 1995). They face the choice to either engage in production or in soldiering for violence specialists. As it is their main objective to maximise their expected income, producers consider the costs and benefits of each option. As explained above, these costs and benefits are determined by the counter-insurgency strategies of the elite coalition and the compensation offered to them by the warlords.

Existing economic theories of rebellions assume that elites in the first stage of the model choose the type and extent of counter-insurgency strategies while taking into account how their choices will affect warlords and producers (Grossman 1995). In the present context, this assumption would imply that the content of peace agreements-and especially the type and extent of their power-sharing provisions-are solely chosen to ward off any potential armed challenges and minimize disruptions due to post-war violence. But past research shows that peace agreements and power-sharing vary widely and are often determined by the nature of the civil war and other contextual factors (Cammett and Malesky 2012; Hartzell and Hoddie

\footnotetext{
${ }^{2}$ Agreement signatories frequently maintain their own armies-as it happened in South Sudan or the Democratic Republic of Congo after 2003. Alternatively, government and rebel units are integrated into a new national army (Glassmyer and Sambanis 2008).
} 
2015; Joshi and Darby 2013; Ottmann and Vüllers 2015). Therefore, some power-sharing arrangements might actually limit elites' abilities to prevent insurrections and rebellions. In the following, I examine in greater detail how this variation in power-sharing across post-war countries affects affects elites, warlords, and producers. I focus on two types: personalized and structural power-sharing arrangements. ${ }^{3}$

\section{The Impact of Power-Sharing}

Personalized power-sharing usually comes in the form of executive power-sharing: government and rebel elites divide up the positions in the national government (Ottmann and Vüllers 2015). Among the most prized positions are obviously the high-profile portfolios of the foreign or defence ministry or the portfolios controlling the exploitation of natural resources. But even smaller and seemingly unimportant positions like the tourism or health ministries are still offering rebel elites unprecedented access to political and material resources (Arriola 2009; Francois, Rainer, and Trebbi 2015).

Thus, personalized power-sharing embodies the essence of an elite coalition between violence specialists established through a peace agreement. It grants the involved government and rebel elites unfettered access to resources for their own private political and economic benefits. At the same time, it prevents warlords from directly accessing these resources. This enables government and rebel elites to implement an effective 'stick-and-carrot' counterinsurgency strategy (Daly 2014; Themnér 2011). They can reward their commanders and fighters and, in doing so, retain tight control over their armed forces. In Sierra Leone, for instance, military reforms integrated large numbers of ex-combatants into the army which reduced the pool of battle-hardened recruits for any potential post-war rebellion (Nilsson and Söderberg Kovacs 2013). Elites can also use their rents to channel resources towards their support networks and reward them for their war-time and post-war support. Agreement signatories in the Democratic Republic of Congo have used these strategies very effectively to maintain their regional strongholds (Tull 2003).

Conversely, personalized power-sharing severely restricts the ability of warlords to organize a post-war rebellion (Lichbach 1995). The 'stick' element of elites' counter-insurgency strategy means warlords have to muster considerable political and material resources to form a credible threat to the elite coalition and its armed organizations. Elites' 'carrot' means that warlords also need more resources to compensate producers for their soldiering and support. Given elites' resource redistribution to producers, the latter will see production-and not soldierung —as the preferred way to maximise their income. Events in South Sudan nicely illustrate this. At least for the time of the national power-sharing government, SPLA elites were able to subdue simmering ethnic tensions within their ranks through extensive redistribution (de Waal 2014).

\footnotetext{
${ }^{3}$ With these two types of power-sharing, I explicitly depart from the common categorization of power-sharing along political, military, economic, or territorial dimensions (Hartzell and Hoddie 2007). As I show in the following discussion, power-sharing in such dimensions frequently follow a similar logic and thus not necessarily warrant a separate analysis. For a similar argument, see Gates et al. (2016).
} 
In contrast, structural power-sharing includes the introduction of proportional representation, quotas guaranteeing specific amounts of parliamentary seats for particular groups and territorial decentralization or even federalism. These arrangements diffuse power initially held by the political centre across political institutions (Hartzell and Hoddie 2007). Electoral systems based on proportional representation and parliamentary quotas, for example, facilitate the sharing of power on the basis of demographic criteria or political affiliations. Ethnic groups, political parties or social classes are given limited but guaranteed access to power (Cammett and Malesky 2012). Territorial decentralization follows a similar logic by shifting power from the capital to sub-national political entities (Bakke 2015; Brancati 2009).

These structural arrangements do not give elites privileged and exclusive access to state resources anymore (North, Wallis, and Weingast 2009). Admittedly, government elites are still occupying their seats in the national executive. Rebel elites also enjoy an improved political standing as agreement signatory and partner to the government. Very often, rebel elites are even able to gain power in the soon-to-be autonomous regions or through national elections. But elites do not have the unchecked and exclusive access to state resources given to them under personalized power-sharing. In the Philippines, for example, the limited powers and ineffective bureaucracy of the Autonomous Region in Muslim Mindanao (ARMM) severely restricted efforts by Nur Misuari and his MNLF to exert regional control and contributed to the emergence of the competing MILF rebels (Bertrand 2000).

This has considerable implications on the 'stick-and-carrot' counter-insurgency strategy available to the elite coalition (Daly 2014; Grossman 1995; Themnér 2011). Reduced privileged access to state resources results in elites having fewer rents at their disposal and, ultimately, less opportunities to reward their commanders and fighters. This weakens elites' control over their armed forces making defections more likely. It also translates into reduced resource redistribution towards producers. Abstention from violence will not necessarily be rewarded anymore. Structural power-sharing thus creates a situation in which the elite coalition is less able to suppress a post-war rebellion.

Structural power-sharing consequently favors warlords and their attempt to organize a postwar insurrection (Choi and Raleigh 2015). Given less effective counter-insurgency strategies, they need fewer recruits and resources for their armed organizations in order to credibly challenge the elite coalition. The compensations given to producers are also lower as reduced resource redistribution towards them means that soldiering for warlords becomes a less costly activity. At the same time, the introduction of new electoral laws, parliamentary quotas or territorial decentralization opens up political space for excluded violence specialists (Brancati 2009; Lijphart 1977). As we can see in the Indonesian provice of Aceh or the Democratic Republic of Congo, these features of post-war orders facilitate the mobilization and recruiting of producers for warlords' armed organizations and support networks and subsequent armed struggles over resource redistribution (Barron, Jaffrey, and Varshney 2016; Reyntjens 2007). 


\section{Empirical Implications}

Two observable implications follow from this theoretical framework. First, we should observe less post-war violence in the presence of personalized power-sharing. These arrangements facilitate effective counter-insurgency strategies which increase the costs for warlords to organize post-war rebellions and reduce producers' expected income from soldiering for warlords.

Hypothesis 1: Personalized power-sharing between government and rebels decreases the amount of post-war violence.

The second implication is that post-war violence increases when a peace agreement sets up structural power-sharing arrangements. These institutions limit the effectiveness of counterinsurgency strategies while opening up political space for political mobilization. In turn, organizing rebellions is less costly for warlords and potentially more profitable for producers.

Hypothesis 2: Structural power-sharing between government and rebels increases the amount of post-war violence.

\section{Data}

To test my argument, I need to identify a sample of post-war situations in which post-war violence can conceivably be influenced by power-sharing between government and rebels. I therefore rely on PSED (Ottmann and Vüllers 2015) and its list of peace agreements signed between 1990 and 2006. The sample covers 65 settlements in 29 African and Asian countries. 48 of them resolved African conflicts and 17 ended Asian wars. The unit of analysis is the peace agreement month.

I exclusively focus on the first five years after each peace agreement. During this volatile period, many of the factors which drove the civil war are still present and power-sharing is likely to have an immediate effect on the calculus of political actors. A post-war situation is removed from the sample in the month when recurring battle violence between the agreement signatories results in more than 25 battle deaths. Such civil war recurrence results in the collapse of the negotiated post-war order. ${ }^{4}$

The regional focus on Africa and Asia ensures that the empirical implications of my theory are tested in "narrow, focused, [and] controlled circumstances" (Clarke 2005, 349) which minimizes the risk of omitted variable bias. Post-war situations in these world regions most closely resemble the previously described post-war orders (North et al. 2013). That is, the

\footnotetext{
${ }^{4}$ About half of the peace agreements (32) experienced a civil war recurrence. However, almost three quarters occurred within the first post-war year. The large majority (87\%) of the 2,319 post-war months under observation represent post-war periods which did not return to civil war. In a robustness check, I explore whether increasing levels of battle violence between government and rebel signatories affect post-war violence. I do not find any supportive evidence for such a relationship.
} 
settlement restructures political order and signatories face the potential of post-war rebellions by excluded violence specialists. In Europe, in contrast, we either observe so-called 'frozen conflicts' or cases in which international organization almost replace state authorities (Cornell 2005; Perry 2009). Finally, peace agreements in the Americas rarely rely on the kind of redistribution of political power embodied by power-sharing (Ottmann and Vüllers 2015).

\section{Dependent Variable}

Post-war violence is defined as any instance of armed violence in a country resulting in battle-related deaths between the actors having signed the peace agreement and any other armed non-state group. Such violence comes in two forms. First, battle violence between the government of a state and a non-signatory armed group; and, second, battle violence between rebel signatories and non-signatory armed groups. ${ }^{5}$ Examples for post-war violence include the aforementioned fighting between government forces and Darfur rebels in the wake of the 2005 CPA in Sudan and the infighting among MNLF factions in the Philippines after the 1996 peace agreement.

I operationalize this dependent variable as the monthly number of battlefield fatalities due to post-war violence after a settlement. I use data from the UCDP Georeferenced Event Dataset (GED) (Sundberg and Melander 2013). Its battlefield fatality measure includes military personnel from the armed groups as well as civilians and unknown victims killed in the crossfire of battle violence.

The advantage of using UCDP GED lies in its strict definition of its actor categories and their temporally disaggregated fatality counts. ${ }^{6}$ Its data structure can be easily matched to PSED data on power-sharing practices. Using UCDP GED also ensures that my post-war violence measure captures all relevant instances of armed clashes between agreement signatories and nonsignatory groups while excluding non-political violence due to criminal activities. Moreover, UCDP GED identifies all instances of battle violence perpetrated by a actor throughout their existence irrespective of a minimum number of fatalities as long as the actor caused 25 battlerelated deaths at least once. This tracing of violence events in previous and subsequent years ensure a relatively comprehensive picture of post-war violence.

\section{Explanatory Variables}

I rely on PSED (Ottmann and Vüllers 2015) to capture personalized and structural powersharing. PSED records the type, extent, and timing of power-sharing practices in the first five

\footnotetext{
${ }^{5}$ Government and rebel signatories in PSED are operationalized in line with UCDP definitions (Gleditsch et al. 2002). I similarly rely on UCDP to operationalize all non-signatory armed groups.

${ }^{6}$ The actor definitions of the Armed Conflict and Location Event Dataset (ACLED) are much looser and a large proportion of their violence events cannot be linked to a specific actor (Raleigh et al. 2010). It would be very difficult to determine whether instances of battle violence after the peace agreement would actually fulfil the criteria for post-war violence outlined above.
} 
years after a peace agreement. In doing so, it does not capture mere promises of power-sharing but records whether it has been actually put into practice. It also captures instances of powersharing which have never been mentioned in a peace agreement. This focus on power-sharing practices is a main advantage of PSED to other data collections as, for example, the UCDP Peace Agreement Dataset (Harbom, Högbladh, and Wallensteen 2006). PSED also provides an exact temporal mapping of power-sharing practices. It records when power-sharing has been established and if and when it has been abolished. The data collection thus accounts for the fact that many power-sharing practices are only temporary. ${ }^{7}$

Personalized power-sharing is operationalized as the occurrence and extent of powersharing on the national executive level. PSED records when representatives of a rebel signatory to a settlement join the national government by taking over a government portfolio. It also records when the rebel representatives leave these positions again. I summarize this information in the variable Personalized Power-Sharing which counts the number of portfolios hold by rebel representatives in a post-war month.

Structural power-sharing encompasses the introduction of territorial power-sharing, parliamentary quotas and proportional representation electoral systems. Territorial power-sharing means the passing of a law or decree enacting regional devolution or granting autonomy to a specific region of a country. Parliamentary quotas are understood as guaranteed seats for rebel groups in the national parliament. Finally, the establishment of a proportional representation electoral system is coded when a corresponding law or decree has been passed. The variable Structural Power-Sharing summarizes this information in a count variable ranging from 0 to 3 capturing the number of arrangements in place in a post-war month.

Personalized power-sharing was established in 28 of the 65 peace agreements and recorded in 827 of all post-war months observations (35\%). The average number of rebel-held portfolios per month is 6 and the maximum number is 21 . In contrast, structural power-sharing was present in 19 post-war periods and 845 observations (36\%). I observe more than one structural arrangement in only 127 of these observations. 12 peace agreements covering 400 post-war months saw personalized as well as structural power-sharing established at some point during the post-war period.

\section{Confounding Variables}

Past research has shown that power-sharing as well as post-war violence are not randomly distributed across post-war countries (Hartzell and Hoddie 2015). The empirical analysis therefore has to account for a number of potentially confounding factors. ${ }^{8}$

\footnotetext{
${ }^{7}$ While the Peace Accords Matrix (PAM) (Joshi and Darby 2013) also includes data on the implementation status of peace agreement provisions, it takes the peace agreement as the starting point and does not record power-sharing practices which have never been agreed upon in the settlement. Data is also only collected yearly and the database itself focuses on a subset of settlements, so-called 'comprehensive peace agreements'.

${ }^{8}$ I provide summary statistics and more information on the operationalization of the control variables in the online appendix.
} 
First, I include the variable Population (ln) (World Bank 2016b). Populous countries are often difficult to rule as they allow for more violence specialists to emerge and offer more potential recruits to these violence specialists (Fearon and Laitin 2003). More populous countries are therefore more likely to see power-sharing and higher post-war fatality counts.

Second, I control for the characteristics of the civil war resolved by the peace agreement. Power-sharing is more likely to occur in protracted civil wars and when the government faces a multitude of armed challengers (Nilsson 2008; Walter 2002). Similar factors are also likely to drive higher levels of post-war violence (Boyle 2014; Nilsson and Söderberg Kovacs 2011). I therefore include the binary indicator Previous Peace Agreements and the count variable Civil War Duration (ln) as controls. The dummy variable Territorial Conflict accounts for the possibility that autonomy conflicts are more likely to see structural power-sharing. Data for these variables is taken from UCDP and PSED (Gleditsch et al. 2002; Ottmann and Vüllers 2015).

Finally, I consider the features of the post-war situation. As I conceptualize power-sharing as a redistributive tool, I use GDP per capita ( $(n)$ to account for the available resources in a post-war country (World Bank 2016a). I also expect ethnic exclusion to affect power-sharing and post-war violence due the prevalence of ethnic mobilization in Africa and Asia (Denny and Walter 2014). I expect post-war violence to be lower, the more previously excluded ethnic groups are considered in the peace agreement (Cunningham and Weidmann 2010). The variable Newly Included Ethnic Groups therefore measures the relative share of formerly excluded ethnic groups which gain access to the political order through their links to rebel signatories (Vogt et al. 2015). Finally, I use Excluded Rebel Groups to control for the number of armed actors excluded from the peace agreement (Gleditsch et al. 2002; Ottmann and Vüllers 2015). The more rebel groups are excluded, the higher the likelihood that some of these groups resort to violence challenging either the government or rebel signatories (Nilsson and Söderberg Kovacs 2011).

\section{Empirical Strategy}

The objective of my analysis is to estimate the effect of personalized and structural powersharing on post-war violence. In particular, I compare the average level of violence in those post-war months with power-sharing to those post-war months without power-sharing.

The dependent variable is a count of the number of post-war battle deaths. It is overdispersed as the conditional variance is greater than the mean. I therefore rely on a negative binomial regression model (NBRM) (Cameron and Trivedi 2013). The NBRM adds a parameter which allows the conditional variance of the dependent variable to exceed the conditional mean. Variation in the dependent variable is due to variation in the independent variables among units over time but also to unobserved heterogeneity introduced by the additional parameter $\epsilon_{i t}$. 
I implement the NBRM using the following regression equation:

$$
\begin{aligned}
{\text { Post-War } \text { Violence }_{i t}=\exp \left(\beta_{0}\right.} & \beta_{1} \text { Personalized Power-Sharing }_{i t} \\
& +\beta_{2} \text { Structural Power-Sharing } i t \\
& \left.+\beta_{3} \mathbf{X}_{i t}+\epsilon_{i t}\right)
\end{aligned}
$$

where Post-War Violence ${ }_{i t}$ represents the number of post-war battlefield fatalities in country $i$ in month $t . \beta_{0}$ is the intercept. Personalized Power-Sharing ${ }_{i t}$ is a count variable measuring the number of rebel-held portfolios in the national government in country $i$ in month $t$. Structural Power-Sharing $i t$ is a count of the number of structural arrangements in country $i$ in month $t .{ }^{9} \mathbf{X}_{i t}$ is a vector of control variables. $\epsilon_{i t}$ is the aforementioned random error that is assumed to be uncorrelated with the independent variables. The term $\exp \left(\epsilon_{i t}\right)$ follows a gamma distribution with mean 1 and variance $\alpha$. I use robust standard errors clustered on the peace agreement to address the possibility that observations within each post-war period are related with each other.

The coefficients of interest for assessing my hypotheses are $\beta_{1}$ and $\beta_{2}$. I expect $\beta_{1}$ to show a negative association between the extent of personalized power-sharing and the number of post-war battle deaths. In contrast, I expect $\beta_{2}$ to reveal a positive association between the number of structural arrangements and post-war battle deaths. To warrant any remotely causal interpretation of these associations, I have to account for the fact that power-sharing as well as post-war violence are not randomly distributed across post-war countries. I address this by including $\mathbf{X}_{i t}$ which includes the aforementioned control variables capturing the selection process of both power-sharing and post-war violence. All covariates in $\mathbf{X}_{i t}$ are time-invariant and measured at the beginning of the post-war period to avoid post-treatment bias.

I explore this 'selection on observables' assumption in three ways. First, I conduct a matching analysis to improve covariate balance and reduce model dependence (Ho et al. 2007). Second, I estimate a fixed effects model and thus assume that power-sharing is independent of potential outcomes as long as any potential confounding variables are time-invariant (Angrist and Pischke 2009). Finally, I explore unobserved selection processes by estimating a series of models including time-varying variables capturing additional post-war processes and events.

\section{Results}

Table 1 reports the NBRM results. ${ }^{10}$ Model 1 only includes the two main explanatory variables measuring personalized and structural power-sharing. I then include key control variables in a stepwise manner in models 2 to 6 . By comparing the minimal model specification of model 1 with models including more covariates, I assess how potentially confounding variables affect

\footnotetext{
${ }^{9}$ Both power-sharing variables are lagged one month in order to ensure temporal order.

${ }^{10}$ The statistical analysis was performed using Stata Statistical Software Version 14 (StataCorp 2015).
} 
Table 1. Effects of Personalized and Structural Power-Sharing on Post-War Battle Deaths

\begin{tabular}{|c|c|c|c|c|c|c|}
\hline & Model 1 & Model 2 & Model 3 & Model 4 & Model 5 & Model 6 \\
\hline Personalized Power-Sharing ( $\mathrm{t}-1)$ & $\begin{array}{c}-0.12^{* *} \\
(0.04)\end{array}$ & $\begin{array}{c}-0.12^{* *} \\
(0.04)\end{array}$ & $\begin{array}{c}-0.15^{* *} \\
(0.05)\end{array}$ & $\begin{array}{c}-0.16^{* * *} \\
(0.04)\end{array}$ & $\begin{array}{c}-0.15^{* *} \\
(0.05)\end{array}$ & $\begin{array}{c}-0.16^{* * *} \\
(0.05)\end{array}$ \\
\hline Structural Power-Sharing (t-1) & $\begin{array}{c}0.57^{+} \\
(0.30)\end{array}$ & $\begin{array}{c}0.57^{+} \\
(0.30)\end{array}$ & $\begin{array}{c}0.73^{* *} \\
(0.27)\end{array}$ & $\begin{array}{c}0.83^{* *} \\
(0.30)\end{array}$ & $\begin{array}{c}0.76^{* *} \\
(0.28)\end{array}$ & $\begin{array}{c}0.95^{* *} \\
(0.33)\end{array}$ \\
\hline \multicolumn{7}{|l|}{ Controls } \\
\hline Population (ln) & & $\begin{array}{c}0.94^{* * *} \\
(0.28)\end{array}$ & $\begin{array}{l}1.20^{* * *} \\
(0.17)\end{array}$ & $\begin{array}{l}1.51^{* * *} \\
(0.44)\end{array}$ & $\begin{array}{l}1.29^{* *} \\
(0.48)\end{array}$ & $\begin{array}{l}1.53^{* * *} \\
(0.43)\end{array}$ \\
\hline Previous Peace Agreement & & & $\begin{array}{c}0.20 \\
(0.48)\end{array}$ & $\begin{array}{c}0.67 \\
(0.62)\end{array}$ & $\begin{array}{c}0.71 \\
(0.61)\end{array}$ & $\begin{array}{c}0.52 \\
(0.63)\end{array}$ \\
\hline Civil War Duration (ln) & & & $\begin{array}{c}-0.00 \\
(0.00)\end{array}$ & $\begin{array}{c}-0.00 \\
(0.00)\end{array}$ & $\begin{array}{c}-0.00 \\
(0.00)\end{array}$ & $\begin{array}{c}-0.00 \\
(0.00)\end{array}$ \\
\hline Territorial Conflict & & & $\begin{array}{c}-2.32^{* * *} \\
(0.49)\end{array}$ & $\begin{array}{c}-1.84^{* * *} \\
(0.55)\end{array}$ & $\begin{array}{c}-1.82^{* * *} \\
(0.54)\end{array}$ & $\begin{array}{c}-1.90^{* * *} \\
(0.54)\end{array}$ \\
\hline GDP per capita (ln) & & & & $\begin{array}{c}-0.39 \\
(0.43)\end{array}$ & $\begin{array}{c}-0.30 \\
(0.44)\end{array}$ & $\begin{array}{c}-0.38 \\
(0.43)\end{array}$ \\
\hline Newly Included Ethnic Groups & & & & $\begin{array}{c}-1.01 \\
(0.88)\end{array}$ & $\begin{array}{c}-0.98 \\
(0.88)\end{array}$ & $\begin{array}{c}-1.12 \\
(0.94)\end{array}$ \\
\hline Excluded Rebel Groups & & & & $\begin{array}{r}0.73^{+} \\
(0.40)\end{array}$ & $\begin{array}{c}0.60 \\
(0.42)\end{array}$ & $\begin{array}{c}0.67 \\
(0.43)\end{array}$ \\
\hline Post-War Battle Deaths (t-1) & & & & & $\begin{array}{c}0.01^{*} \\
(0.00)\end{array}$ & \\
\hline Post-War Duration & & & & & & $\begin{array}{c}0.01 \\
(0.06)\end{array}$ \\
\hline Post-War Duration (squared) & & & & & & $\begin{array}{c}0.00 \\
(0.00)\end{array}$ \\
\hline Post-War Duration (cubed) & & & & & & $\begin{array}{c}-0.00 \\
(0.00)\end{array}$ \\
\hline Constant & $\begin{array}{l}2.50^{* * * *} \\
(0.35)\end{array}$ & $\begin{array}{c}-13.56^{* *} \\
(4.54)\end{array}$ & $\begin{array}{c}-17.55^{* * * *} \\
(2.74)\end{array}$ & $\begin{array}{c}-14.65^{* * * *} \\
(3.01)\end{array}$ & $\begin{array}{c}-13.06^{* * * *} \\
(3.15)\end{array}$ & $\begin{array}{c}-15.06^{* * *} \\
(3.13)\end{array}$ \\
\hline lnalpha & $\begin{array}{l}3.10^{* * * *} \\
(0.27)\end{array}$ & $\begin{array}{c}2.92^{* * *} \\
(0.28)\end{array}$ & $\begin{array}{l}2.81^{* * *} \\
(0.29)\end{array}$ & $\begin{array}{c}2.75^{* * *} \\
(0.30)\end{array}$ & $\begin{array}{c}2.73^{* * *} \\
(0.31)\end{array}$ & $\begin{array}{c}2.75^{* * *} \\
(0.30)\end{array}$ \\
\hline Observations & 2319 & 2319 & 2319 & 2287 & 2228 & 2287 \\
\hline Log Pseudo-Likelihood & -3777.71 & -3705.79 & -3660.86 & -3544.28 & -3450.74 & -3540.66 \\
\hline
\end{tabular}

The table reports NBRM estimates. The unit of observation is the post-war month. Robust standard errors are clustered on peace agreements. $^{+},{ }^{*},{ }^{* *}$, and ${ }^{* * *}$ indicate statistical significance at the $10,5,1$, and $0.1 \%$ levels.

the relationship between power-sharing and post-war violence.

The coefficients of the two power-sharing variables behave as predicted. Personalized PowerSharing has a negative sign and is statistically significant at $p<0.01$ or lower in all models. With an increasing number of rebel-held seats in a national power-sharing government, the amount of post-war battle deaths decreases. It appears that personalized power-sharing makes it less likely that armed groups emerge which are capable of mounting an armed challenge to the government, rebel group signatories or both. The coefficient of Structural Power-Sharing has a positive sign and is statistically significant at conventional levels in all estimated models. The level of post-war battle deaths increases, the more structural arrangements are in place. Apparently, structural power-sharing encourages armed groups outside of the peace agreement to attack government and rebel signatories. 
The control variables included in models 2 to 6 address potential omitted variable bias and thus strengthen a more substantive interpretation of my estimates. Population is positive and highly statistically significant in all estimated models. Territorial Conflict is the only statistically significant covariate of the set of control variables capturing the legacies of the past civil war. We are likely to see less post-war fatalities when the peace agreement concludes a-geographically rather limited-autonomy conflict. None of the covariates accounting for the characteristics of the post-war situtation reaches statistical significance.

In models 5 and 6, I probe whether the amount of post-war violence is a function of time. While my theoretical argument rejects an interpretation of such violence as mere residual of civil war violence, it might still be possible that post-war violence is driven by unobserved factors that strongly correlate with the passage of time since the signature of the peace agreement. I first include the dependent variable lagged one post-war month as additional independent variable to account for previous levels of post-war violence. I include the number of postwar months and its squared and cubic polynomials in model 6 . The direction and statistical significance of Personalized Power-Sharing and Structural Power-Sharing remain unaffected in these two models. While I find that previous levels of post-war violence do matter, Post-War Duration and its polynomials are not statistically significant predictors.

I explore the robustness of the results with a series of alternative model specifications. ${ }^{11}$ Amongst other things, I use the Poisson regression model as alternative statistical estimator and employ robust standard errors clustered on countries. I also estimate model 4 on samples comprising post-war period of 12, 24, 36 and 48 months. Finally, I substitute some of the control variables with alternative measures to guard against an arbitrary choice of covariates. The main results presented above do not change substantially in any of these robustness checks.

\section{Substantive Effects}

Next, I evaluate the substantive effects of power-sharing on post-war violence. I use the observed-value approach by Hanmer and Kalkan (2013) to estimate the average effect in the sample under analysis. I hold the control variables at the observed value for each case in the sample and then average the estimated prediction for the explanatory variables of interest for each case over all of the cases in the sample.

Figure 2 plots the mean of the predicted post-war battle deaths and 90\% confidence intervals for each type of power-sharing under analysis. The average effect of Personalized Power-Sharing on Post-War Battle Deaths ranges from 25 monthly fatalities for zero rebel-held government portfolios to 2 monthly fatalities for the maximum number of 21 portfolios. But given the actual occurrences of personalized power-sharing in my sample, I focus on a more limited range: A change from zero rebel-held portfolios to the mean value of 2 already reduces the monthly fatality count by 6 to an average of about 19 battle deaths. If the number of rebel

\footnotetext{
${ }^{11}$ Detailed results of all robustness checks are presented in the online appendix.
} 
Figure 2. Predicted Post-War Battle Deaths for the Number of Personalized and Structural Power-Sharing Arrangements
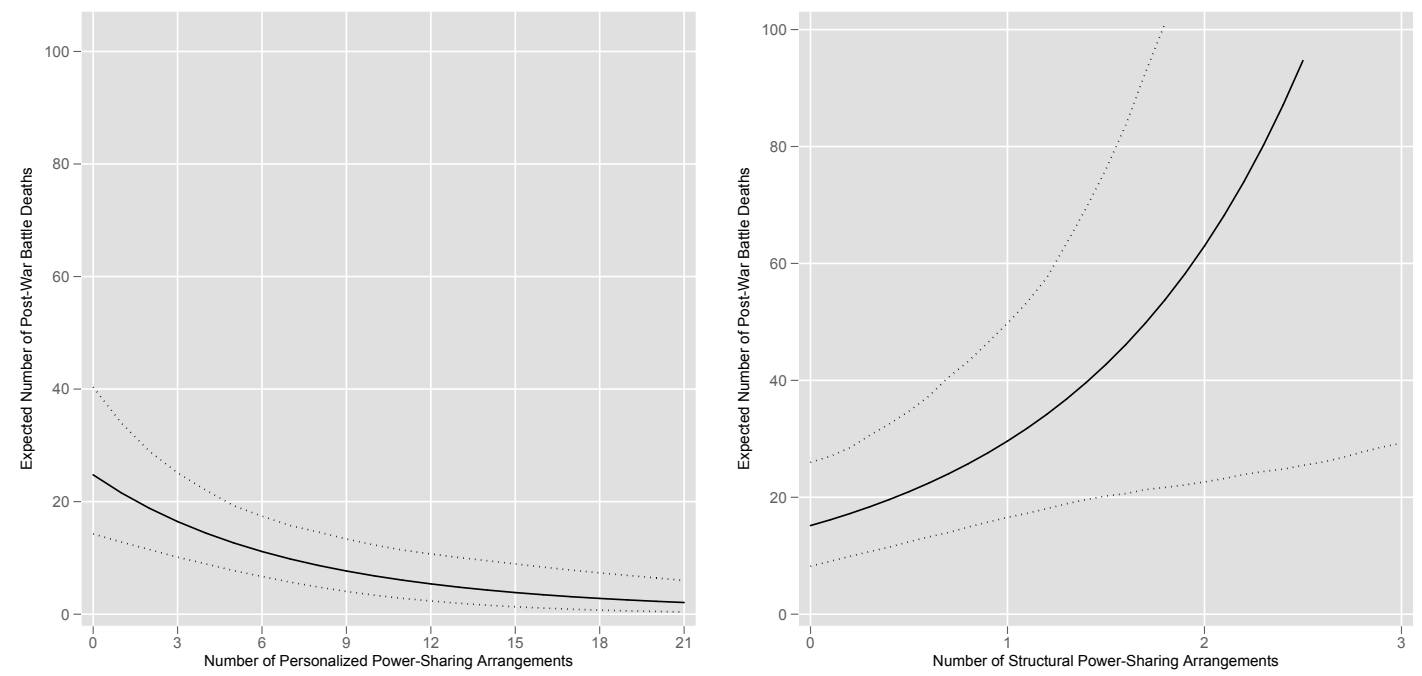

Note: Predicted post-war battle deaths are estimated using Hanmer and Kalkan (2013)'s observed-value approach, based on Model 2 reported in Table 1. Dotted lines indicate $90 \%$ confidence intervals around predicted counts. To improve comparability, both plots use the same scale on the $y$-axis. The right-hand side plot depicting the substantive effects of Structural Power-Sharing on Post-War Battle Fatalities is therefore truncated. I report the predictions over their full range in the online appendix.

portfolios is further increased by its standard deviation to 6 positions, we see an average effect of only 11 fatalities per month. The number of post-war battle deaths has effectively been halved.

The opposite is true for the effect of structural power-sharing on post-war violence. Figure 2 indicates that the number of post-war battle deaths sharply increases the more of these arrangements are in place. The predicted counts range from 15 post-war fatalities for zero structural arrangements to 145 fatalities when three arrangements have been implemented. However, it is again important to consider the actual distribution of Structural Power-Sharing in the sample under analysis. In 718 of 845 post-war months with structural power-sharing in place, there is only one of these arrangements in place. But even in these cases, the fatality count already doubles from 15 to 30 . In the 108 observations with two arrangements, the fatality count doubles once again and jumps to 62 post-war battle deaths. We then observe sharply widening confidence intervals as only 19 observations feature three structural arrangements.

These results imply that power-sharing can have a substantial effect on the levels of post-war violence. Personalized power-sharing enables government and rebel signatories to effectively suppress violent challenges to the post-war order. In contrast, structural power-sharing appears to facilitate the emergence of violent challenges to the ruling post-war elites. 


\section{Probing the 'Selection on Observables' Assumption}

Any causal interpretation of the reported findings rests on the assumption that personalized and structural power-sharing are independent of potential outcomes conditional on the covariates included in $\mathbf{X}_{i t}$. I investigate this 'selection on observables' assumption with a matching analysis and fixed effects model.

Matching preprocesses the data under analysis so that untreated observations (months without any power-sharing) are as similar as possible to treated observations (months where power-sharing is in place). Regression estimates obtained from such a matched dataset are less dependent on the values of the control variables and their functional forms (Ho et al. 2007). I rely on 'Coarsened Exact Matching' (CEM) which sorts observations into coarsened strata and then prunes any observation whose stratum does not contain at least one treated and one control unit (Iacus, King, and Porro 2012). In doing so, CEM reduces imbalance in the sample based on all properties of the covariate distributions and makes no assumptions about the underlying data generation process.

To identify treatment and control groups, CEM requires a dichotomous 'treatment' variable. I therefore summarize my two explanatory variables with a binary indicator measuring whether either personal and/or structural power-sharing is present in a post-war month. This is a justifiable simplification for the matching analysis. While I expect that personalized and structural power-sharing each have a different effect on post-war violence, power-sharing in general is likely to be driven by the same selection process. Similarly, the extent of power-sharing is due to the particular manifestations of the covariates capturing this selection process. ${ }^{12}$ I use the binary power-sharing variable together with all control variables included in model 4 to preprocess the data using the CEM algorithm. ${ }^{13}$ The control variables are coarsened with the cut-points set at the $1^{\text {th }}, 25^{\text {th }}, 50^{\text {th }}, 75^{\text {th }}$ and $99^{\text {th }}$ percentile. ${ }^{14}$

Table 2 reports the regression results of re-estimating model 4 using this matched dataset. ${ }^{15}$ The coefficients of Personalized Power-Sharing and Structural Power-Sharing in model 7 are both statistically significant and their direction in line with my hypotheses. But, importantly, CEM only focuses on the sample average treatment effect on the treated as the quantity of interest (Iacus, King, and Porro 2012). The obtained coefficients therefore only describe the effect of power-sharing on post-war violence in the range of cases where power-sharing actually occurred.

In a separate robustness check, I estimate a fixed effects specification of model 4 in order to

\footnotetext{
${ }^{12}$ I explore this assumption with two additional matched datasets using dichotomous variables for each type of power-sharing as separate 'treatment' variables. Estimates of model 4 using these two matched datasets do not differ substantially from the results presented here. Full results are presented in the online appendix.

${ }^{13}$ I implement CEM in Stata with the cem package (Blackwell et al. 2009).

${ }^{14}$ The overall $\mathcal{L}_{1}$ statistics-a comprehensive measure of global imbalance-is greatly reduced in the matching solution. This indicates that the overall balance in the data has been considerably increased.(Iacus, King, and Porro 2012). A more detailed discussion of the imbalance statistics can be found in the online appendix.

${ }^{15}$ I include all control variables to account for any residual variation in the matched dataset (Ho et al. 2007). However, these coefficients should not be interpreted substantively and I therefore do not report them.
} 
Table 2. Matching and Correlated Random Effects

\begin{tabular}{lccc}
\hline & Model 7: & \multicolumn{2}{c}{ Model 8: } \\
& $\begin{array}{c}\text { Coarsened } \\
\text { Exact }\end{array}$ & Correlated Random Effects \\
\cline { 3 - 4 } & Matching & Within & Between \\
& & Effects & Effects \\
\hline Personalized Power-Sharing (t-1) & $-0.14^{* * *}$ & $-0.07^{*}$ & $-0.22^{* * *}$ \\
& $(0.04)$ & $(0.03)$ & $(0.06)$ \\
Structural Power-Sharing (t-1) & $1.34^{* * *}$ & $0.53^{*}$ & $0.95^{* *}$ \\
& $(0.37)$ & $(0.25)$ & $(0.33)$ \\
Constant & -5.57 & $-14.91^{* * *}$ & $-14.91^{* * *}$ \\
& $(5.42)$ & $(2.84)$ & $(2.84)$ \\
lnalpha & $2.63^{* * *}$ & $2.75^{* * *}$ & $2.75^{* * *}$ \\
& $(0.30)$ & $(0.31)$ & $(0.31)$ \\
\hline Controls & Yes & Yes & Yes \\
Observations & 1669 & 2287 & 2287 \\
Log Pseudo-Likelihood & -2236.21 & -3539.91 & -3539.91 \\
\hline
\end{tabular}

The table reports NBRM estimates. The unit of observation is the post-war month. All models are estimated with the control variables included in Model 4. Full results are presented in the online appendix. Robust standard errors are clustered on peace agreements. ${ }^{+},{ }^{*},{ }^{* *}$, and ${ }^{* * *}$ indicate statistical significance at the $10,5,1$, and $0.1 \%$ levels.

adjust for unobserved time-invariant confounders. So far, I have assumed that the covariates included in $\mathbf{X}_{i t}$ adequately capture the selection process of both power-sharing and post-war violence. To explore this assumption, I exploit the fact that the data under analysis offer repeated observations for each post-war period in the sample. With data at multiple time periods, a fixed effects specification allows us to discount omitted variable bias as long as any potential confounders are time-invariant (Angrist and Pischke 2009). If there is unobserved heterogeneity, it has to stem from time-varying confounders.

As the conditional fixed effects NBRM cannot be seen as a true fixed effect model, I conduct this robustness check with a correlated random effects (CRE) model (Allison 2005). The CRE model controls out any unobserved heterogeneity by averaging over time the time-varying observations for each post-war period and then subtracting these averages from the observed values of the variables. Obtained estimates for these within effects are identical to fixed effects estimates. The CRE model also includes additional terms capturing the post-war period mean of each time-varying covariate together with the time-invariant covariates to the model. Obtained estimates at this level represent the effects of power-sharing between post-war periods.

The within effects coefficients for Personalized Power-Sharing and Structural Power-Sharing reported in Table 2 do not differ from the main results lending additional support to my hypotheses. The estimates do not seem to be biased by unobserved time-invariant confounders. Decomposing the summary statistics of my power-sharing variables into within and between components, it also becomes apparent that the within effects still represent a meaningful effect. With a standard deviation of 2.3 within post-war periods over time, Personalized Power-Sharing still shows considerable variation (overall standard deviation: 4.38). The same applies to Structural Power-Sharing which has a within-unit standard deviation of 0.34 (overall standard 
Table 3. Alternative Explanations for Post-War Violence

\begin{tabular}{|c|c|c|c|c|}
\hline & Model 9 & Model 10 & Model 11 & Model 12 \\
\hline Personalized Power-Sharing (t-1) & $\begin{array}{c}-0.16^{* * *} \\
(0.05)\end{array}$ & $\begin{array}{c}-0.16^{* *} \\
(0.05)\end{array}$ & $\begin{array}{c}-0.16^{* * *} \\
(0.04)\end{array}$ & $\begin{array}{c}-0.16^{* * *} \\
(0.04)\end{array}$ \\
\hline Structural Power-Sharing (t-1) & $\begin{array}{c}0.83^{* *} \\
(0.29)\end{array}$ & $\begin{array}{c}1.03^{* *} \\
(0.37)\end{array}$ & $\begin{array}{c}0.80^{* *} \\
(0.30)\end{array}$ & $\begin{array}{c}0.82^{* *} \\
(0.29)\end{array}$ \\
\hline \multicolumn{5}{|l|}{ Alternative Explanations } \\
\hline Within-Agreement Battle Deaths, t- 1 & $\begin{array}{c}0.00 \\
(0.00)\end{array}$ & & & \\
\hline UN Peacekeeping, t-1 & & $\begin{array}{c}-0.58 \\
(0.59)\end{array}$ & & \\
\hline Rebel-Military Integration, t-1 & & & $\begin{array}{r}-1.31^{*} \\
(0.52)\end{array}$ & \\
\hline Elections (3 Months) & & & & $\begin{array}{c}-1.23^{\text {*** }} \\
(0.28)\end{array}$ \\
\hline Constant & $\begin{array}{c}-14.58^{* * *} \\
(3.03)\end{array}$ & $\begin{array}{c}-15.72^{* * *} \\
(3.61)\end{array}$ & $\begin{array}{c}-14.63^{* * *} \\
(2.97)\end{array}$ & $\begin{array}{c}-14.50^{* * *} \\
(2.97)\end{array}$ \\
\hline lnalpha & $\begin{array}{c}2.76^{* * *} \\
(0.31)\end{array}$ & $\begin{array}{c}2.75^{* * *} \\
(0.30)\end{array}$ & $\begin{array}{c}2.75^{* * *} \\
(0.30)\end{array}$ & $\begin{array}{l}2.74^{* * *} \\
(0.30)\end{array}$ \\
\hline Controls & Yes & Yes & Yes & Yes \\
\hline Observations & 2228 & 2287 & 2287 & 2287 \\
\hline Log Pseudo-Likelihood & -3459.16 & -3542.25 & -3541.88 & -3539.47 \\
\hline
\end{tabular}

The table reports NBRM estimates. The unit of observation is the post-war month. All models are estimated with the control variables included in Model 4. Full results are presented in the online appendix. Robust standard errors are clustered on peace agreements. ${ }^{+},{ }^{*},{ }^{* *}$, and ${ }^{* * *}$ indicate statistical significance at the $10,5,1$, and $0.1 \%$ levels.

deviation: 0.62). The between effects are also in line with my previous findings. Post-war periods with personalized power-sharing are likely to experience lower levels of post-war violence than those without it. Likewise, post-war periods with structural arrangements are on average more likely to experience higher levels of post-war violence.

\section{Accounting for Alternative Explanations}

Finally, there is the possibility that my regression results are biased by time-varying confounders. Table 3 reports the results of four models exploring these potentially competing explanations. ${ }^{16}$

A first alternative explanation is that post-war violence simply increases in tandem with violence between the government and rebel signatories. If the peace agreement is fragile and recurrence of large-scale violence likely, either side might rely on officially unaffiliated armed groups to avoid responsibility for the ultimate breakdown of the settlement (Carey, Colaresi, and Mitchell 2015). Increasing levels of battle violence between government and rebels might also encourage previously inactive armed groups to position themselves in a new round of fighting. I explore this through including the variable Within-Agreement Battle Violence in Model 9. It captures monthly battle deaths between government and rebel signatories (Sundberg and

\footnotetext{
${ }^{16}$ As in the previously estimated models, all independent variables are lagged one post-war month to ensure temporal order.
} 
Melander 2013). However, the coefficient is statistically not significant and the main results remain stable.

A second alternative explanations concerns the presence of United Nations (UN) peacekeeping forces. Hultman, Kathman, and Shannon (2014) show that the presence of UN peacekeepers reduces the number of battle deaths during and after civil war. Their presence mitigates the commitment problem between armed groups and increases the costs of continued fighting. I use the IPI Peacekeeping Database (Perry and Smith 2013) to construct the binary variable UN Peacekeeping. Its coefficient in model 10 is not statistically significant and the power-sharing variables are not affected.

Another alternative explanation focuses on the occurrence of rebel-military integration after war. While scholars are skeptical whether rebel-military integration prevents the collapse of a peace agreement (Glassmyer and Sambanis 2008; Krebs and Licklider 2016), they might be able to prevent the post-war armed challenges to government forces or rebel signatory troops. After all, rebel-military integration limits the availability of battle-hardened fighters for newly emerging groups. To account for this possibility, I add the variable Rebel-Military Integration into model 11. Taken from PSED (Ottmann and Vüllers 2015), this variable indicates when a rebel-military integration event took place in a given month of the post-war period. While its coefficient is indeed negative and statistically significant, the main findings do not change.

A final alternative explanation would be that post-war elections drive levels of post-war violence (Brancati and Snyder 2013; Flores and Nooruddin 2012). Elections create winners and losers. In a post-war situation losing an election might not only threaten the political survival of elites and their followers but also their physical survival. Election winners might use their new-found power to get rid of their opponents once and for all. Model 12 therefore includes the binary variable Post-War Elections which indicates the month leading up to a post-war election, the month it takes place and the month following it (Ottmann and Vüllers 2015). In doing so, I account for the possibility that electoral violence does not occur directly before or after the election date. I find that post-war elections have a statistically significant negative effect on post-war violence. This notwithstanding, the power-sharing variables retain their direction and statistical significance.

\section{Discussion}

Power-sharing does not only create security commitments between government and rebel signatories. They also regulate the extent to which these former conflict actors can access state resources and use this privileged access to secure their rule throughout the post-war country. Especially personalized power-sharing enables elites to reward their fighters and supporters and thus maintain their violent capabilities. It also allows them to offer incentives for peaceful behavior to citizens of the post-war country. As a consequence, excluded elites face increasing costs when they mobilize for a post-war rebellion. In contrast, structural power- 
sharing limits the privileged access to state resources of peace agreement signatories. They have less resources available for effective counter-insurgency strategies and excluded violence specialists therefore face fewer costs in mobilizing citizens for a post-war rebellion. I argue that the implications of this political economy model are observable through the amount of post-war violence occurring between agreement signatories and any other armed organization.

I test my propositions using conceptually and temporally disaggregated data on on powersharing and post-war violence in African and Asian countries emerging from civil war between 1990 and 2006. I am able to show that personalized power-sharing consistently decreases the amount of post-war violence whereas structural arrangements increase it. These findings hold even when controlling for a range of potential confounders capturing the legacies of civil war and characteristics of the post-war country. In addition, the results remain robust when probing the selection of potential confounders using matching methods, fixed effects models, and alternative explanations. I interpret these regression results as empirical expression of the fact that power-sharing shapes resource redistribution and, thus, ruling elites' ability to suppress post-war rebellions.

The theoretical and empirical contributions of this study open up several avenues for future research. My main objective was to complement existing theoretical approaches of powersharing after civil war with a political economy perspective. In a next step, the uncovered relationships between power-sharing, resource redistribution, and post-war violence need to be examined more closely. We require more information on the impact of power-sharing on different types of state resources and rent extraction and how they are redistributed. To understand variation in post-war violence, we also need to shed light on the pathways linking government and rebel elites in the center of a post-war country to mid-level brokers in the periphery who ultimately reward supporters. Equally important is a refined understanding of sub-national patterns of political violence and repression. While the presented model of power-sharing and post-war violence did not yield any geographical implications, further studies should explore in which regions we should expect political violence to occur-be it in the form of riots, tribal clashes or even full-blown civil war. Similarly, it is necessary to look in greater detail on the post-war state and its repertoire of repressive instruments.

Finally, the empirical findings of this study speak to the policy discussion of power-sharing as a common tool of conflict resolution. In line with more recent studies (Cederman et al. 2015; Gates et al. 2016; Graham, Miller, and Strøm 2017; Hartzell and Hoddie 2015), I find that power-sharing is not the sine qua non of successfully promoting post-war peace. Different types of power-sharing and how they are combined with each other can have very different effects on political violence. Structural power-sharing, for instance, often comes with serious negative consequences for post-war violence. At least in the short-term, personalized power-sharing might act as a counterweight. Then again, such arrangements entrench existing rulers and their patronage networks which might be detrimental to long-term peace and prosperity. There is no straightforward solution to this dilemma. Rather, policy makers have to be aware of these trade-offs and design their interventions with a view towards citizens on the ground and the 
broader post-war order.

\section{References}

Allison, Paul D. 2005. Fixed Effects Regression Methods for Longitudinal Data Using SAS. SAS Institute.

Angrist, Joshua D., and Jörn-Steffen Pischke. 2009. Mostly Harmless Econometrics: An Empiricist's Companion. Princeton, NJ: Princeton University Press.

Arriola, Leonardo R. 2009. "Patronage and Political Stability in Africa." Comparative Political Studies 42(10): 1339-1362.

Bakke, Kristin M. 2015. Decentralization and Intrastate Struggles. Chechnya, Punjab, and Quebec. Cambridge: Cambridge University Press.

Barron, Patrick, Sana Jaffrey, and Ashutosh Varshney. 2016. "When Large Conflicts Subside: The Ebbs and Flows of Violence in Post-Suharto Indonesia." Journal of East Asian Studies 16(2): 191-217.

Bertrand, Jacques. 2000. "Peace and Conflict in the Southern Philippines: Why the 1996 Peace Agreement Is Fragile." Pacific Affairs 73(1): 37-54.

Binningsbø, Helga Malmin. 2013. "Power Sharing, Peace and Democracy: Any Obvious Relationships?" International Area Studies Review 16(1): 89-112.

Blackwell, Matthew, Stefano M. Iacus, Gary King, and Giuseppe Porro. 2009. "Cem: Coarsened Exact Matching in Stata." Stata Journal 9(4): 524-546.

Boyle, Michael J. 2014. Violence after War: Explaining Instability in Post-Conflict States. JHU Press.

Brancati, Dawn. 2009. Peace by Design. Managing Intrastate Conflict Through Decentralization. Oxford: Oxford University Press.

Brancati, Dawn, and Jack L. Snyder. 2013. "Time to Kill: The Impact of Election Timing on Postconflict Stability." Journal of Conflict Resolution 57(5): 822-853.

Cameron, A. Colin, and Pravin K. Trivedi. 2013. Regression Analysis of Count Data. Second Edition. Cambridge: Cambridge University Press.

Cammett, Melani, and Edmund Malesky. 2012. "Power Sharing in Postconflict Societies: Implications for Peace and Governance.” Journal of Conflict Resolution 56(6): 982-1016.

Carey, Sabine C., Michael P. Colaresi, and Neil J. Mitchell. 2015. "Governments, Informal Links to Militias, and Accountability." Journal of Conflict Resolution 59(5): 850-876. 
Cederman, Lars-Erik, Simon Hug, Andreas Schädel, and Julian Wucherpfennig. 2015. "Territorial Autonomy in the Shadow of Conflict: Too Little, Too Late?" American Political Science Review 109(2): 354-370.

Cheng, Christine, and Dominik Zaum. 2013. "Selling the Peace? Corruption and Post-Conflict Peacebuilding." In Corruption and Post-Conflict Peacebuilding: Selling the Peace?, eds. Christine Cheng, and Dominik Zaum. London: Routledge , 1-25.

Choi, Hyun Jin, and Clionadh Raleigh. 2015. "Dominant Forms of Conflict in Changing Political Systems." International Studies Quarterly 59(1): 158-171.

Clarke, Kevin A. 2005. "The Phantom Menace: Omitted Variable Bias in Econometric Research." Conflict Management and Peace Science 22(4): 341-352.

Cornell, Svante. 2005. Small Nations and Great Powers: A Study of Ethnopolitical Conflict in the Caucasus. Routledge.

Cunningham, Kathleen Gallagher. 2011. "Divide and Conquer or Divide and Concede: How Do States Respond to Internally Divided Separatists?" American Political Science Review 105(2): 275-297.

Cunningham, Kathleen Gallagher, and Nils B. Weidmann. 2010. "Shared Space: Ethnic Groups, State Accommodation, and Localized Conflict." International Studies Quarterly 54(4): 10351054.

Cunningham, Kathleen Gallagher, Kristin M. Bakke, and Lee J. M. Seymour. 2012. "Shirts Today, Skins Tomorrow: Dual Contests and the Effects of Fragmentation in Self-Determination Disputes." Journal of Conflict Resolution 56(1): 67-93.

Daly, Sarah Zukerman. 2014. "The Dark Side of Power-Sharing: Middle Managers and Civil War Recurrence." Comparative Politics 46(3): 333-353.

de Waal, Alex. 2014. "When Kleptocracy Becomes Insolvent: Brute Causes of the Civil War in South Sudan." African Affairs 113(452): 347-369.

Denny, Elaine K, and Barbara F Walter. 2014. "Ethnicity and Civil War." Journal of Peace Research 51(2): 199-212.

Fearon, James D., and David D. Laitin. 2003. "Ethnicity, Insurgency, and Civil War." American Political Science Review 97(1): 75-90.

Flores, Thomas Edward, and Irfan Nooruddin. 2012. "The Effect of Elections on Postconflict Peace and Reconstruction." The Journal of Politics 74(2): 558-570.

Francois, Patrick, Ilia Rainer, and Francesco Trebbi. 2015. "How Is Power Shared in Africa?" Econometrica 83(2): 465-503. 
Gates, Scott, Benjamin A. T. Graham, Yonatan Lupu, Håvard Strand, and Kaare W. Strøm. 2016. "Power Sharing, Protection, and Peace." The Journal of Politics 78(2): 512-526.

Glassmyer, Katherine, and Nicholas Sambanis. 2008. "Rebel-Military Integration and Civil War Termination." Journal of Peace Research 45(3): 365-384.

Gleditsch, Nils Petter, Peter Wallensteen, Mikael Eriksson, Margareta Sollenberg, and Håvard Strand. 2002. "Armed Conflict 1946-2001: A New Dataset." Journal of Peace Research 39(5): 615-637.

Graham, Benjamin a. T., Michael K. Miller, and Kaare W. Strøm. 2017. "Safeguarding Democracy: Powersharing and Democratic Survival.” American Political Science Review 111(4): 686704.

Grossman, Herschel I. 1995. "Insurrections." In Handbook of Defense Economics. Vol. 1 Elsevier , 191-212.

Haass, Felix, and Martin Ottmann. 2017. "Profits from Peace: The Political Economy of Power-Sharing and Corruption." World Development 99: 60-74.

Hanmer, Michael J., and Kerem Ozan Kalkan. 2013. "Behind the Curve: Clarifying the Best Approach to Calculating Predicted Probabilities and Marginal Effects from Limited Dependent Variable Models." American Journal of Political Science 57(1): 263-277.

Harbom, Lotta, Stina Högbladh, and Peter Wallensteen. 2006. "Armed Conflict and Peace Agreements." Journal of Peace Research 43(5): 617-631.

Hartzell, Caroline A., and Matthew Hoddie. 2007. Crafting Peace: Power-Sharing Institutions and the Negotiated Settlement of Civil Wars. University Park, PA: Pennsylvania State University Press.

Hartzell, Caroline A., and Matthew Hoddie. 2015. "The Art of the Possible: Power Sharing and Post-Civil War Democracy." World Politics 67(1): 37-71.

Ho, Daniel E., Kosuke Imai, Gary King, and Elizabeth A. Stuart. 2007. "Matching as Nonparametric Preprocessing for Reducing Model Dependence in Parametric Causal Inference." Political Analysis 15(3): 199-236.

Hultman, Lisa, Jacob Kathman, and Megan Shannon. 2014. "Beyond Keeping Peace: United Nations Effectiveness in the Midst of Fighting." American Political Science Review 108(4): 737753.

Iacus, Stefano M., Gary King, and Giuseppe Porro. 2012. "Causal Inference without Balance Checking: Coarsened Exact Matching." Political Analysis 20(1): 1-24.

Joshi, Madhav, and John Darby. 2013. "Introducing the Peace Accords Matrix (PAM): A Database of Comprehensive Peace Agreements and Their Implementation, 1989-2007." Peacebuilding 1(2): 256-274. 
Kalyvas, Stathis N. 2006. The Logic of Violence in Civil War. Cambridge: Cambridge University Press.

Krebs, Ronald R., and Roy Licklider. 2016. "United They Fall: Why the International Community Should Not Promote Military Integration after Civil War." International Security 40(3): 93138.

Lichbach, Mark Irving. 1995. The Rebel's Dilemma. Ann Arbor, MI: University of Michigan Press.

Lijphart, Arend. 1977. Democracy in Plural Societies: A Comparative Exploration. Yale University Press.

Mattes, Michaela, and Burcu Savun. 2009. "Fostering Peace After Civil War: Commitment Problems and Agreement Design." International Studies Quarterly 53(3): 737-759.

Nilsson, Desirée. 2008. "Partial Peace: Rebel Groups Inside and Outside of Civil War Settlements." Journal of Peace Research 45(4): 479-495.

Nilsson, Desirée, and Mimmi Söderberg Kovacs. 2011. "Revisiting an Elusive Concept: A Review of the Debate on Spoilers in Peace Processes." International Studies Review 13(4): 606-626.

Nilsson, Desirée, and Mimmi Söderberg Kovacs. 2013. "Different Paths of Reconstruction: Military Reform in Post-War Sierra Leone and Liberia." International Peacekeeping 20(1): 216.

North, Douglass C., John Joseph Wallis, and Barry R. Weingast. 2009. Violence and Social Orders. A Conceptual Framework for Interpreting Recorded Human History. Cambridge: Cambridge University Press.

North, Douglass C., John Joseph Wallis, Steven B. Webb, and Barry R. Weingast, eds. 2013. In the Shadow of Violence. Politics, Economics, and the Problem of Development. Cambridge: Cambridge University Press.

Ottmann, Martin, and Johannes Vüllers. 2015. "The Power-Sharing Event Dataset (PSED): A New Dataset on the Promises and Practices of Power-Sharing in Post-Conflict Countries." Conflict Management and Peace Science 32(3): 327-350.

Perry, Chris, and Adam C. Smith. 2013. Trends in Uniformed Contributions to UN Peacekeeping: A New Dataset, 1991-2012. Vol. [accessed on 17 February 2016] International Peace Institute.

Perry, Valery. 2009. "At Cross Purposes? Democratization and Peace Implementation Strategies in Bosnia and Herzegovina's Frozen Conflict." Human Rights Review 10(1): 35-54.

Raleigh, Clionadh, Andrew Linke, Håvard Hegre, and Joakim Karlsen. 2010. "Introducing ACLED: An Armed Conflict Location and Event Dataset: Special Data Feature." Journal of Peace Research 47(5): 651-660. 
Reyntjens, Filip. 2007. "Briefing: Democratic Republic of Congo: Political Transition and Beyond." African Affairs 106(423): 307-317.

Roessler, Philip. 2016. Ethnic Politics and State Power in Africa: The Logic of the Coup-Civil War Trap. Cambridge University Press.

StataCorp. 2015. Stata Statistical Software: Release 14. College Station, TX: StataCorp LP.

Sundberg, Ralph, and Erik Melander. 2013. "Introducing the UCDP Georeferenced Event Dataset." Journal of Peace Research 50(4): 523-532.

Themnér, Anders. 2011. Violence in Post-Conflict Societies: Remarginalization, Remobilizers and Relationships. Routledge.

Tull, Denis M. 2003. "A Reconfiguration of Political Order? The State of the State in North Kivu (DR Congo)." African Affairs 102(408): 429-446.

Vogt, Manuel, Nils-Christian Bormann, Seraina Rüegger, Lars-Erik Cederman, Philipp Hunziker, and Luc Girardin. 2015. "Integrating Data on Ethnicity, Geography, and Conflict: The Ethnic Power Relations Data Set Family." Journal of Conflict Resolution 59(7): 1327-1342.

Walter, Barbara F. 2002. Committing to Peace: The Successful Settlement of Civil Wars. Princeton, NJ: Princeton University Press.

Walter, Barbara F. 2004. "Does Conflict Beget Conflict? Explaining Recurring Civil War." Journal of Peace Research 41(3): 371-388.

Weinstein, Jeremy M. 2007. Inside Rebellion: The Politics of Insurgent Violence. Cambridge: Cambridge University Press.

World Bank. 2016a. "GDP (Current US\$)." https ://data.worldbank.org/indicator/ NY. GDP .MKTP . CD.

World Bank. 2016b. "Population, Total." https://data.worldbank.org/indicator/SP. POP. TOTL? view=chart. 